\title{
Learnings from Developing a Context-Specific LCA Tool for Buildings-The Case of LCAbyg 4
}

\author{
Kai Kanafani *(D), Regitze Kjær Zimmermann (D), Freja Nygaard Rasmussen and Harpa Birgisdóttir (D) \\ Department of the Built Environment, Aalborg University, 2740 Aalborg, Denmark; rkz@build.aau.dk (R.K.Z.); \\ fnr@build.aau.dk (F.N.R.); hbi@build.aau.dk (H.B.) \\ * Correspondence: kak@build.aau.dk
}

Citation: Kanafani, K.;

Kjær Zimmermann, R.;

Nygaard Rasmussen, F;

Birgisdóttir, H. Learnings from

Developing a Context-Specific LCA

Tool for Buildings-The Case of

LCAbyg 4. Sustainability 2021, 13,

1508. https://doi.org/10.3390/

su13031508

Academic Editor: Vladimír Kočí

Received: 9 December 2020

Accepted: 26 January 2021

Published: 1 February 2021

Publisher's Note: MDPI stays neutral with regard to jurisdictional claims in published maps and institutional affiliations.

\begin{abstract}
Buildings are a major cause of global resource consumption, greenhouse gas (GHG) emissions and other impacts on the environment, originating from both operational energy and material use. Informed design decisions can help mitigate potential impacts on the environment, by the use of life cycle assessment (LCA) in the early project stages. In order to mitigate building environment impacts throughout the industry, architects and engineers need tools that are integrated in the design workflow and based on the information available. Existing LCA tools for building design professionals are predominantly embedded in a specific context such as a country or a sustainability scheme. This paper provides learnings for the development of context-tailored tools for building-LCA using the case of Denmark, with specific focus on GHG-emissions that are in focus worldwide. Based on stakeholder involvement, four key areas were defined: Default information, flexibility, environmental design feedback and transparent results. Tool functions include a component library and a quantity estimator for bridging incomplete building information. A comparison monitor displays the performance of design solutions selected in the model, while a number of graphs and tables provide analysis of inventory and results. Finally, a customisable model data export, a complete input/output file for revision and custom analysis are among key functions for transparency.
\end{abstract}

Keywords: LCA tool; life cycle assessment; integrated design process; design tool; Greenhouse Gas emissions; LCA; environmental impact assessment

\section{Introduction}

With the Paris agreement, many countries have agreed on committing to limit global warming to 2.0 degrees with an aspiration to 1.5 degrees. The national target for Denmark has been set to a 70\% greenhouse gas (GHG) emissions reduction by 2030 compared to 1990 [1]. The building sector, representing almost 40\% of GHG emissions [2], is a pivotal area of action in achieving this aim. For several decades, policies on energy efficiency in new [3] and existing buildings [4] have been implemented. Currently, the goal is to achieve buildings with zero operational energy by 2050. As emissions caused by the operational energy use of new buildings have decreased, the share of embodied emissions has grown [5-9]. Therefore, a whole-life perspective of building GHG emissions should be applied.

Benchmarks for building GHG emissions have predominantly existed in procurement programmes and certification schemes [10,11]. National legal emission limits are still uncommon [12], but several countries have issued rules for assessing GHG emissions based on the life cycle assessment (LCA) method, thus creating a foundation for later regulatory frameworks [12-16]. While more environmental impact categories should be considered in order to ensure a holistic environmental perspective, these emerging LCAbased regulation efforts are mainly focussing on GHG emissions, driven by the current political climate action.

In order to mitigate GHG emissions, architects and engineers strongly need LCA tools for making informed design decisions [17], especially during the early design stages, where 
major decisions are made [18-20]. However, the complexity of LCA is often perceived a barrier for implementation of LCA in building design [21-24]. LCA tools can potentially make the analysis methods and data handling accessible for building consultants. Hence, a well-considered tool design can deliver reliable and valid results while keeping the extra workload for LCA implementation in the design process to a minimum.

The main concern here is to embed LCA into the specific context of the consultancy processes, in order to avoid time-consuming adjustments at the level of the individual consultancy. To be feasible for the industry, the tool must therefore meet the specific national context, including building regulation, information flow, design method and construction method.

The second major precondition refers to the LCA method itself. European standardisation of building LCA [25] is leaving a considerable definition gap between theory and practice [26,27]. This means that specific national adjustments of the LCA method $[14,15,28-30]$ are needed to close definition gaps, strengthen the use of LCA in the industry, and create momentum for meeting climate mitigation targets. Adjustments include the definitions of system boundaries, scenarios, emission factors, service life of materials, data quality and reporting format.

Existing tools for whole building LCA such as Athena Impact Estimator [31], Baubook eco2soft [32], the plug-in Caala [33], eLCA [34], One Click LCA [35], Anavitor [36] and $\mathrm{BM}$ [37] are, therefore, tailored to each of their specified regional contexts, aiming to provide user-friendly integration into the design process. Some examples exist on the practical uptake of LCA in the building sector $[23,27]$ and the requirements for developing LCA-tools for building design [22]. However, there is a knowledge gap in research literature about the context of the LCA tool application, and the influence this context has on the tool design.

This paper exhibits and analyses the development of the Danish building-LCA tool LCAbyg with the aim of providing learnings for the development of context-tailored tools for building-LCA. The novel perspective lies in linking the general LCA methodology with the specific context of the user. Guiding research questions for this paper consist of the following: (1) What types of requirements for building-LCA tools are prevalent in a Danish context? (2) How are the implemented features evaluated by building professionals and which future directions for development does this point to?

\section{Materials and Methods}

The 2014 building strategy by the Danish government [38] pinpointed the introduction of a voluntary sustainability class in the building regulations as a key goal, and the development of national building-LCA definitions, as well as a tool, as important milestones.

The initial version of the LCAbyg tool was launched in 2015 under the auspices of the Danish building authorities [39,40]. Prior to the development, an advisory council representing a broad range of future users and other interested parties was established. During workshops and dialogue with the advisory council, the Department of the Built Environment (BUILD) developed the first LCAbyg release [41]. The present paper refers to LCAbyg version 4 [42], which was released in 2019.

A range of the LCA methods implemented in the LCAbyg originate from the development of the 2014-version of the LCAbyg tool. A major influence on the tool development has been the implementation of the building certification scheme DGNB (Deutsche Gesellschaft für Nachhaltiges Bauen) in Denmark in 2010 [43]. The DGNB adaptation process included the selection of the life cycle impact assessment (LCIA) database Ökobaudat [44] as a source for national generic environmental data. Using Ökobaudat ensures compliancy of generic environmental product data with the European Standard (EN) 15804:2012 [45] standard for LCA on building products. LCAbyg further complies with the LCA calculation method in the European Standard EN 15978:2012 [25] standard for LCA on whole buildings, albeit including only a selection of life cycle stages and impact categories: LCAbyg supports the product stage and the modules for replacements, energy use, waste processing and disposal (Figure 1). The selection of the life cycle stages and impact categories is the result of sectoral 
consultation in the initial DGNB implementation. LCAbyg supports the following ten categories of environmental impacts and resource uses, according to EN 15978/15804:2012:

- Global warming potential total;

- Depletion potential of the stratospheric ozone layer;

- Acidification potential;

- Eutrophication potential freshwater;

- Formation potential of tropospheric ozone;

- Abiotic depletion potential for non-fossil resources;

- Abiotic depletion potential for fossil resources;

- Use of renewable primary energy excluding renewable primary energy resources used as raw materials;

- Use of non-renewable primary energy excluding non-renewable primary energy resources used as raw materials;

- Use of non-renewable secondary fuels.

\begin{tabular}{|c|c|c|c|c|c|c|c|c|c|c|c|c|c|c|c|c|}
\hline \multicolumn{3}{|c|}{ Product Stage } & \multicolumn{2}{|c|}{$\begin{array}{l}\text { Construction } \\
\text { Process Stage }\end{array}$} & \multicolumn{7}{|c|}{ Use Stage } & \multicolumn{4}{|c|}{$\begin{array}{l}\text { End of Life } \\
\text { Stage }\end{array}$} & $\begin{array}{l}\text { Benefits and Loads } \\
\text { Beyond the System }\end{array}$ \\
\hline 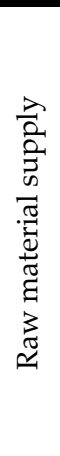 & 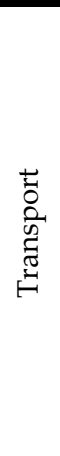 & 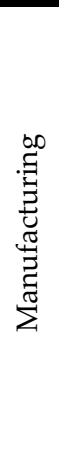 & 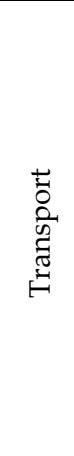 & 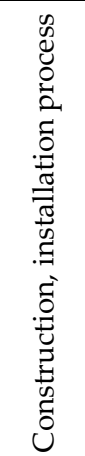 & م. & 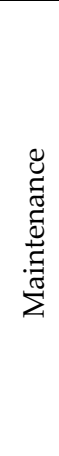 & 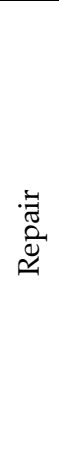 & 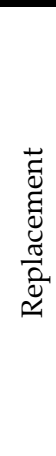 & 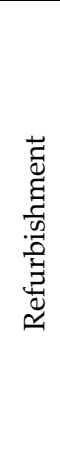 & 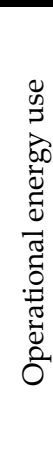 & 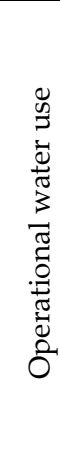 & 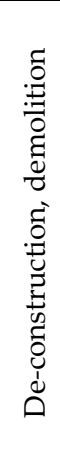 & 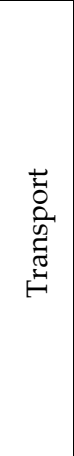 & 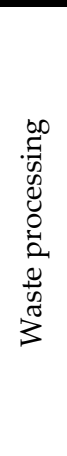 & $\begin{array}{l}\bar{w} \\
0 \\
0 \\
.00 \\
.00\end{array}$ & 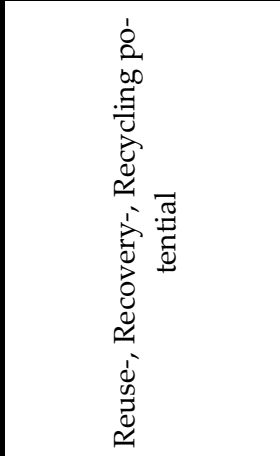 \\
\hline A1 & A2 & A3 & $\mathrm{A} 44^{1}$ & $\mathrm{~A} 5^{1}$ & B1 & B2 & B3 & B4 & B5 & B6 & \begin{tabular}{|l} 
B7 \\
\end{tabular} & $\mathrm{C} 1$ & $\mathrm{C} 2$ & $\mathrm{C} 3$ & $\mathrm{C} 4$ & $\mathrm{D}^{1}$ \\
\hline
\end{tabular}

${ }^{1}$ Modules available in the next tool version

Figure 1. Life cycle according to EN 15978:2011 [25]. Modules included in the tool are highlighted. Reproduced with permission from the Danish Standards Foundation.

The selection of the categories is highly dependent on the data available in Environmental Product Declarations (EPD) for construction materials as well as in the Ökobaudat. The characterization model in use is the CML-IA characterisation method [46], in accordance with the standard. The LCIA database already includes the characterisation step, and the process is therefore not part of LCAbyg.

The legally mandatory operational energy calculations supplements the approximate whole life approach based on available data. Other methodological definitions include the development of default reference study periods for building types and component service life [47]. Finally, emission factors for energy production in Denmark, based on the national energy planning, were published and included in LCAbyg [48].

From the first release, users could provide feedback on the tool via a permanent support mailbox, used for debugging and collecting user feedback for later tool improvements. Together with feedback from the courses for professionals held regularly by the developing team from BUILD, a constant input of ideas and requests for new features was established, and basic usability principles of the software were established [40,41]. In a 2018 project, the user interface was revised to facilitate LCA screenings at early design stages [49]. Table 1 outlines the extensive user involvement in this project $[50,51]$. The workshops, consultations and hearings of items 1-6 in Table 1 provided the empirical 
background for generating the user requirements for the LCAbyg tool development. The seven training courses of items $7-8$ in Table 1 provided the testing and evaluation of the tool features.

Table 1. User involvement in the project prior to the 2018 LCAbyg 4 release.

\begin{tabular}{|c|c|c|c|c|}
\hline No. & Activity & Topic & $\begin{array}{c}\text { Participant } \\
\text { (Main Profile) }\end{array}$ & Participant (No.) \\
\hline 1 & Workshop 1 & $\begin{array}{c}\text { Preconditions for early } \\
\text { design LCA }\end{array}$ & Architects, civil engineers, drafters & 18 \\
\hline 2 & Workshop 2 & tool requirements & Civil engineers & 7 \\
\hline 3 & Workshop 3 & \multirow{2}{*}{$\begin{array}{l}\text { Component library } \\
\text { development }\end{array}$} & \multirow{2}{*}{$\begin{array}{l}\text { Delegates from consultancies, } \\
\text { contractors, manufacturers }\end{array}$} & \multirow{2}{*}{12} \\
\hline 4 & Industry consultation & & & \\
\hline 5 & Industry hearing & \multirow{2}{*}{$\begin{array}{l}\text { Component library } \\
\text { evaluation }\end{array}$} & \multirow{2}{*}{$\begin{array}{l}\text { Delegates from consultancies, } \\
\text { contractors, manufacturers }\end{array}$} & \multirow{2}{*}{30} \\
\hline 6 & Workshop 4 & & & \\
\hline 7 & Course $1-5$ & Training/tool test & Architects, civil engineers, drafters & 99 \\
\hline 8 & Course $6-7$ & Training/tool test & Drafter students & 72 \\
\hline 9 & Workshop 5 & $\begin{array}{c}\text { Design guide } \\
\text { publication [52], } \\
\text { discussion of first draft }\end{array}$ & Architects, civil engineers, drafters & 21 \\
\hline
\end{tabular}

The tool was tested in a series of one-day training courses for building professionals held throughout the country (Table 1). There was a total of 99 participants, of which $37 \%$ were architects, $28 \%$ engineers, $18 \%$ drafters and $7 \%$ other building professionals. The objective was to provide LCA training for professionals and, at the same time, test to what degree the tool is able to affect design decisions by providing specific LCA information. The participants were asked to bring one of their projects, preferably in the early design stages, for performing two LCA exercises: First, modelling the as-is state and then reducing GHG emissions through design variations. The only information given beforehand was a beginner-level presentation of the LCA method and the required tool functions. Overall, $79 \%$ of participants had never conducted an LCA before; however, $55 \%$ had more than 10 years professional experience in the building industry. Participants were asked to respond to two questionnaires, at the beginning (Table A1) and at the end of the course (Table A2). The first questionnaire concerned the profile of the participant, and the place of employment. In the second questionnaire, participants described their specific project: project stage, available documentation, and their opinion on the usability of the tool. From the 99 asked participants, 71 submitted a complete pair of questionnaires, which were used in this study (72\% response rate). The questionnaire was conducted using the tool SurveyXact [53].

\section{Results and Discussion}

\subsection{Stakeholder Requirements for Tool}

The development of the tool was driven by four objectives, both evolving from stakeholder involvement and framed by a political strategy of increasing the use of LCA in building practice:

- Available default data and settings;

- Versatility;

- Environmental feedback for informing design;

- Transparent results.

The user requirements identified through the development process are presented in Table 2. 
Table 2. User requirements and tool features.

\begin{tabular}{|c|c|}
\hline User Requirement & Tool Feature \\
\hline Available default data and settings & $\begin{array}{l}\text { - Curated translation and implementation of the LCIA } \\
\text { database Ökobaudat; } \\
\text { - Standard component service life; } \\
\text { - } \quad \text { Emission factors for delivered energy; } \\
\text { - } \quad \text { Compodar building element structure for design optimisation; } \\
\text { - } \quad \text { Inverial choice; } \\
\text { - }\end{array}$ \\
\hline Versatility & $\begin{array}{l}\text { - } \quad \text { Model data exchange; } \\
\text { - } \quad \text { Exportable graphs and tables; } \\
\text { Optional data input, i.e., for Building Information Modelling (BIM) } \\
\text { integration (requires user script); } \\
\text { - } \quad \text { LCA method applicable for new buildings, renovations or demolitions; } \\
\text { Different complexity levels from screening/sketch design to as-built LCA. }\end{array}$ \\
\hline Environmental feedback for informing design & $\begin{array}{l}\text { - LCA results available in real-time; } \\
\text { - Component library displaying environmental impact; } \\
\text { - } \quad \text { Auick performance comparison during modelling; } \\
\text { - Analysis graphs and tables including hotspot. }\end{array}$ \\
\hline Transparent results & $\begin{array}{l}\text { - } \quad \text { EN 15978:2012 compliancy; } \\
\text { - } \quad \text { Report generator (pdf); } \\
\text { - } \quad \text { Transparency on method and user-defined preconditions; } \\
\text { - } \quad \text { Input model analysis tables; } \\
\text { - } \quad \text { Project comparison. }\end{array}$ \\
\hline
\end{tabular}

\subsection{Tool Overview}

The LCA tool LCAbyg version 4 was released as a beta in January 2019. An overview on the main tool elements is given in Figure 2. At the core, the LCA model represents the inventory of a given project. In order to enhance usability, different kinds of default data are integrated in the tool as well. It includes product and component libraries, service life, and assumptions on quantity estimation. Depending on the stage of the building project or the goal and scope of the LCA, inputs can vary from detailed and specific to using mostly, or only, default data. However, user input must at least include information on floor area and operational energy. Further, default components have to be selected from the library and their quantities specified. These quantities can also be estimated by the tool. This requires the user to add basic building properties usually available in the design stage. The amount of default data in the project can be adjusted at all times. The tool generates a result report and input/output data files. Model data can be exchanged in proprietary file formats both ways. Manufacturers have made use of this possibility by publishing their EPD data as provisional LCAbyg material-files. These files can be downloaded and imported into the tool by users. 


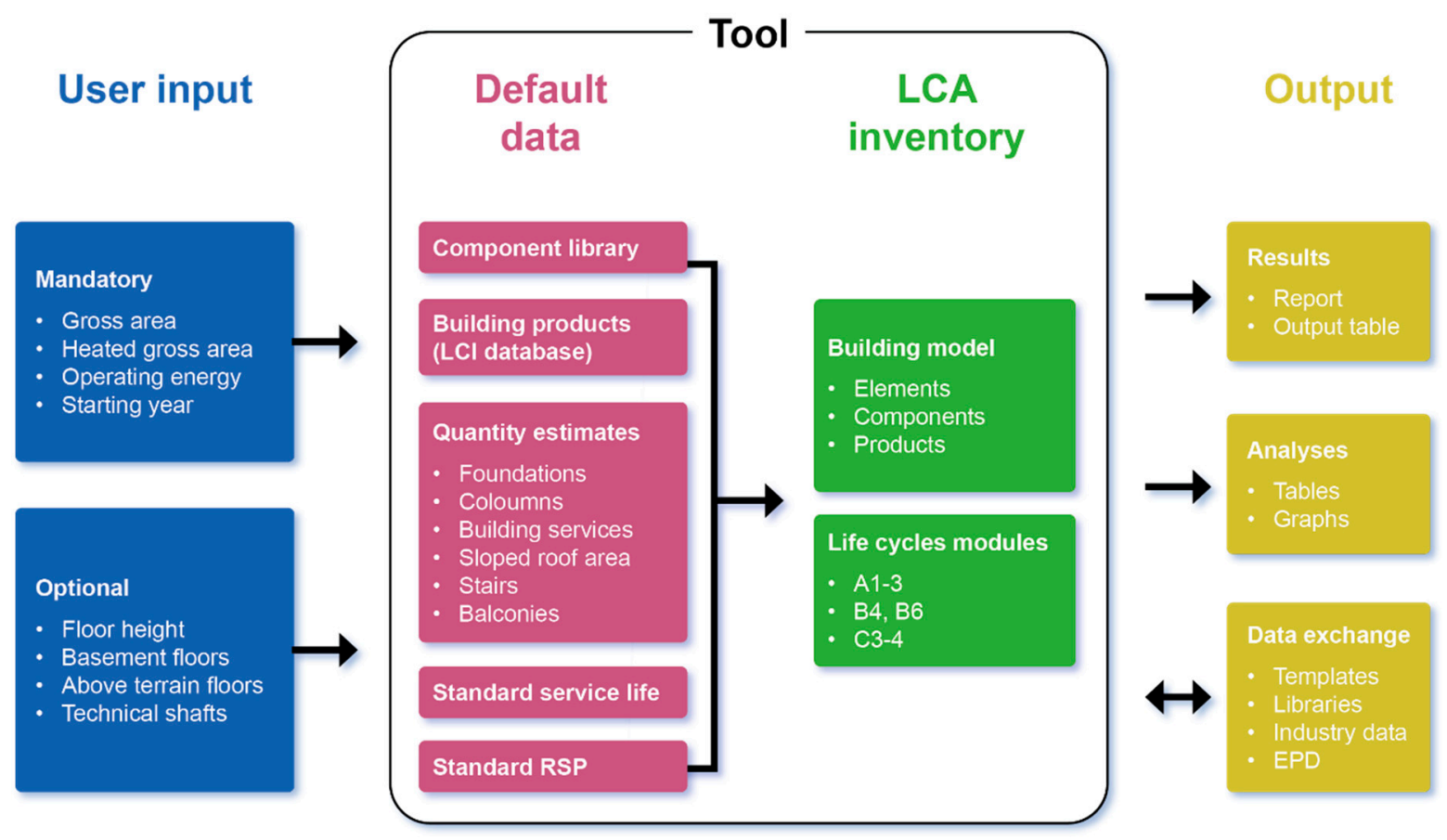

Figure 2. Tool overview.

The subsequent sections are divided into the above-mentioned usability topics and present the responding tool features. Each subsection discusses how the implemented tool features support usability by referring to the user survey results and the literature.

\subsection{Tool Features-Available Default Data and Settings}

3.3.1. Building Model Structure

Default data help users establish a complete inventory regardless of project stage and LCA level of detail, based on the currently available information. The backbone of the complete inventory is the integrated model structure for the inventory (Figure 3), linking building materials with environmental information. When using a simplified approach, users can focus on optimising building design by modelling only on element and component level. Thereby, interaction with the environmental data can be avoided. The Ökobaudat database delivering environmental information is represented on the levels of products and of life cycle modules.

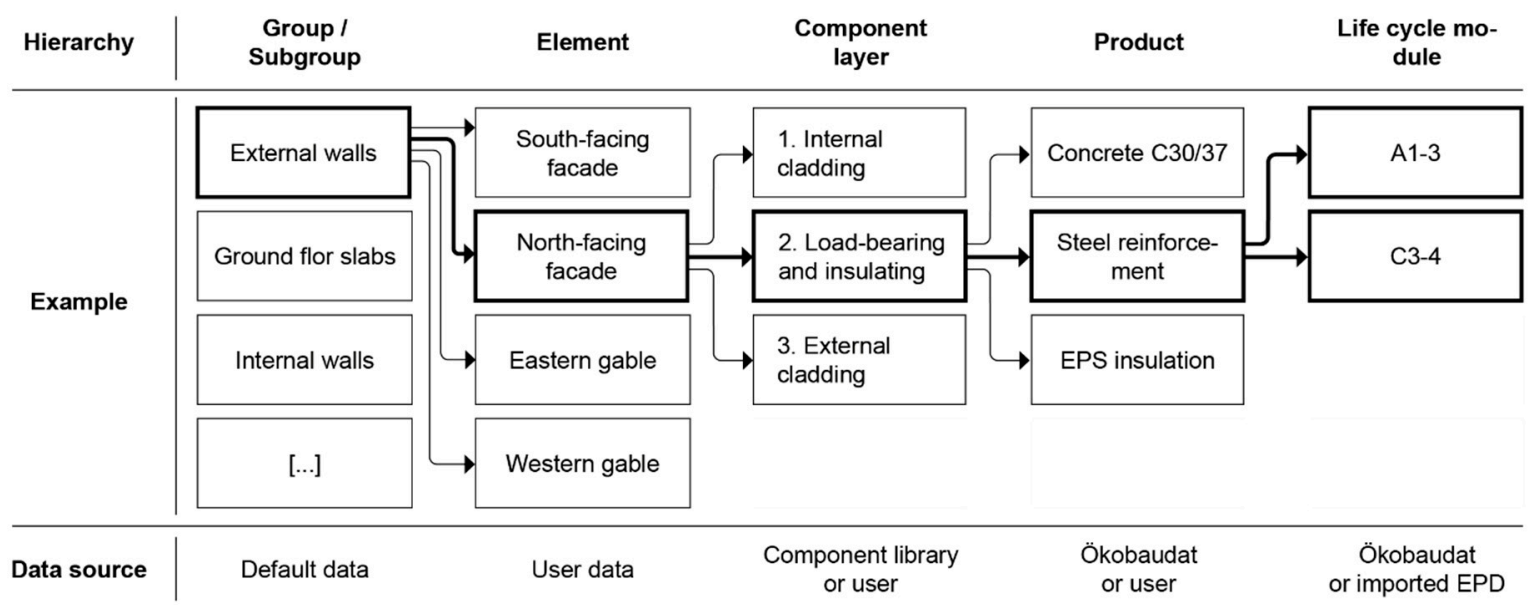

Figure 3. Building model structure. 


\subsubsection{Component Library}

The component library consists of 375 predefined building components. They cover typical solutions and variants for the building types: Detached home, multi-storey apartment building, office building and educational institutions. The components were selected and developed by the LCAbyg team with contributions from consulting architects, engineers, manufacturers and contractors. All predefined building components consist of details about material use per unit of construction, typically per $\mathrm{m}^{2}$. These material uses are linked directly to the environmental impacts determined by the Ökobaudat LCIA database. The technical quality and variety of the library was evaluated by an external consultant. Solutions are modelled following a conservative approach of over- rather than underestimating quantity, material selection and impacts. A test has shown that results for LCA based on default components and available default quantities exceed a detailed, specific modelling approach by maximum $20 \%$ [51].

Inspired by an earlier LCA tool [18], components are defined as one out of three functional component layers, which constitute each building element (Figure 3, Table 3). The three-layer structure introduces a new aggregation level between elements and products, targeting design decisions and performance optimisation. As each layer follows a logical function, designers can explore alternatives with low emissions in the library among components of the same layer. On the building element level, the user can combine the component layers to make a complete element. Table 3 shows how the layer structure is manifested for each element group.

Table 3. Component layers and their function.

\begin{tabular}{cccc}
\hline Element Group & Comp. Layer 1 & Comp. Layer 2 & Comp. Layer 3 \\
\hline Foundations & Foundations & - & - \\
\hline Ground floor slabs & Flooring & Load-bearing system & Insulation and underlay \\
\hline External walls & Inside finishing & Load-bearing and insulating system & Façade system \\
\hline Internal walls & Finishing & Load-bearing and insulating system & Finishing \\
\hline Floor decks & Flooring & Load-bearing and insulating system & Ceiling \\
\hline Stairs and ramps & Structure & Flooring & Balustrades and handrails \\
\hline Columns and beams & Columns and beams & - & - \\
\hline Balconies & Platform & - & Ceiling \\
\hline Roofs & Roof cladding & Load-bearing and insulating system & Solar shading \\
\hline Windows, doors, glazing systems & Profiles & Panes & Terminal unit \\
\hline Building services & Production unit & Distribution & \\
\hline
\end{tabular}

Calculation of impacts from module B6, the operational energy consumption, requires user input on the demand as well as the energy source. Two energy grid scenarios can be selected, a static scenario and a dynamic scenario based on projections of the national energy production until year 2050.

The idea behind the function with default components was to offer the most typical solutions, which may be sufficient in screening LCA, but can be adapted to more specific detailing when needed. The survey respondents preferred to have a component library with a greater variety. This result, however, has to be seen in the context of the LCA training. Here, respondents had experienced not being able to find perfectly suited default solutions during their exercises, because they were asked not to adjust components or generate custom components. Some commented, accordingly, that the need for more default components was less important, as they knew about the general possibility of adjusting components. Others pointed out that default components cannot possibly match specific projects completely. 
The technical quality of default components was predominantly rated neutral (73\%) or rather good. No detailed comments on the quality were given. Both might be due to the lack of time to assess the quality in a one-day course, as one respondent stated.

\subsubsection{Quantity Estimation Guide}

Based on building information available in sketch design, the tool can assist in estimating quantities of building components such as roof area, length of ventilation ducts or the length of strip foundations.

A quantity estimation guide appears automatically, on the right side of the modelling pages, as soon as a sub-element with available quantity estimates is activated (Figure 4). A textbox on top of the guide explains the underlying assumptions and formulae as well as help for choosing items in the form. The calculated quantity is transferred to the subelement by a click. Estimations depend on the element subgroups, see Figure 3. The estimations use mandatory and optional user input (Figure 2) along with simple geometrical information such as the building perimeter or number of apartment units. Some of the estimations merely exploit already made user inputs, for instance the calculation of the sloped roof area using the formula (GFA/no. of floors)/cos (slope angle). Estimations for building services, balconies, and foundations use integrated default values retrieved from industry practice. The tool's quantity estimator was rated positively by $52 \%$, while $38 \%$ submitted neutral replies. Furthermore, $10 \%$ replied negatively; however, five out of these seven "not useful" ratings were justified by already available quantities in their project, therefore lacking the need for estimations.

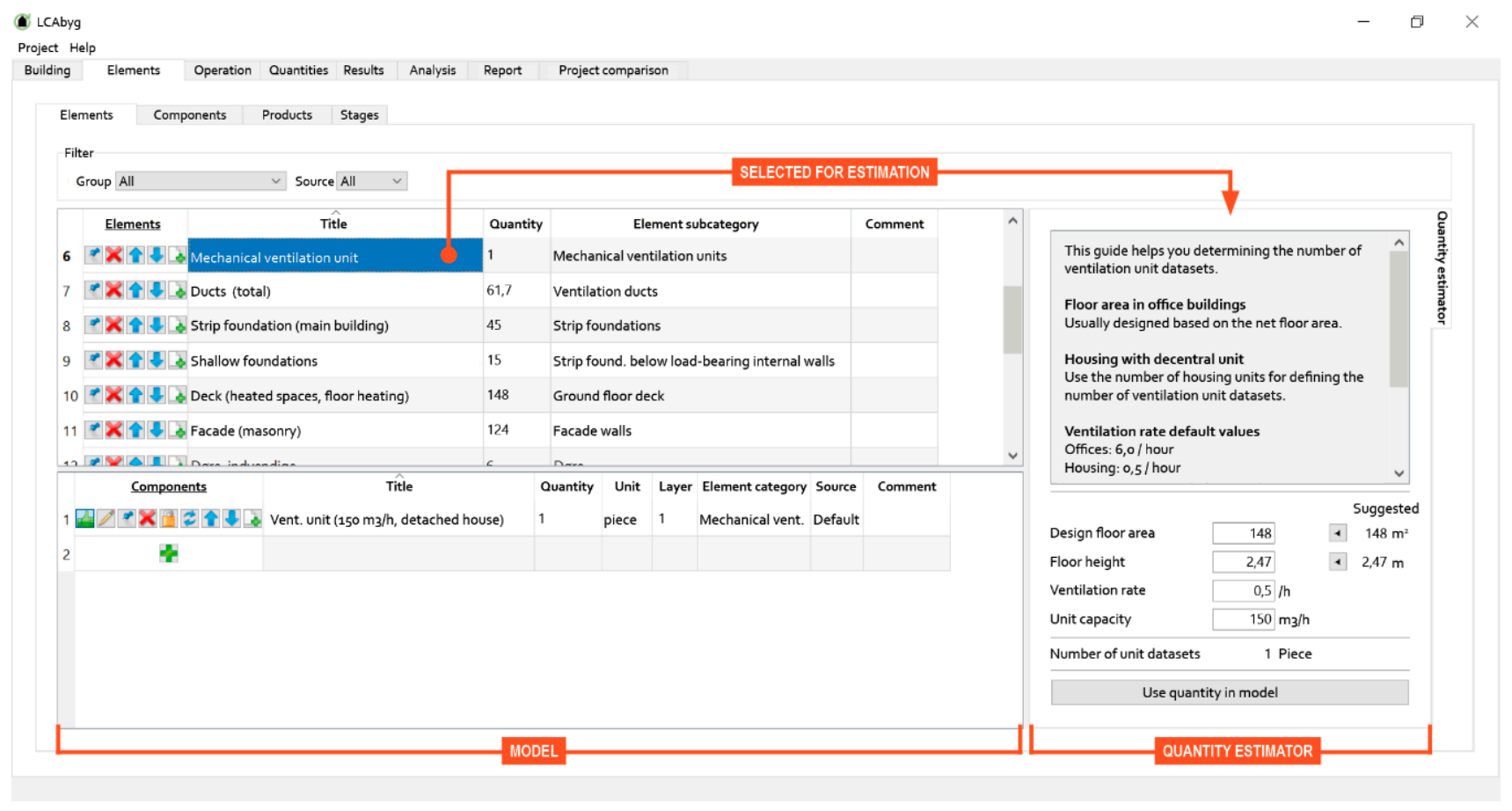

Figure 4. Quantity estimation guide.

\subsection{Tool Feature-Versatility}

\subsubsection{User Profile and Level of Assessment}

The tool can be used for LCA of new buildings, renovations or demolitions. Renovations include newly installed components and waste management of removed parts. A feature that allows the calculation of shares of component life cycles based on the remaining service life is under development for the next tool version. 
Another model is to perform simple assessments during sketch design or architectural competitions in the development team, and then consult the corporate environmental analyst in later stages of the project. However, the possibility of exchanging data from different sources and across different projects requires that data can be organised and managed in the tool. Currently, data can be created, copied, deleted or edited on all instances, either in the containing folder or in a list view. For labelling information, users can rename items or attach comments. However, a visual data organization with a file and folder tree and advanced preview, labelling or editing options could be a meaningful extension. Further, user libraries are saved in project files and are not embedded in the tool itself. An improvement would be the possibility of linking the tool to shared libraries, where manufacturers can submit components and products such as Baubook [54].

\subsubsection{Model Data Exchange}

Data exchange is allowed on all levels of the model hierarchy including building components, products or life cycle modules. Users can make libraries or corporate templates outside the tool using LCAbyg file types for each instance. Performance comparisons in the modelling sections and results of the analysis can be saved as tables and image files. Users can integrate this information in reports and presentations or use the information for subsequent analyses. The tool can read xml-files, which may be produced by BIM tools, thus transferring material and quantity data. This solution requires the user to write a script, which is not part of the tool.

Interfaces between performance analyses and graphical design tools are a major point of interest and discussion [55]. The survey data from the training courses confirm that projects apply numerous workflows and design platforms relating to the diversity of company profiles, contract types, project scales or typologies. Variation also occurs within the course of a project, where some use 2D or 3D CAD models in sketch design and eventually use BIM at later stages, while others apply BIM from the start. Overall, $61 \%$ of the participants' projects were either using BIM or expecting to do so later on. However, only $8 \%$ expressed a demand for linking BIM to the tool. One of the key tasks is mapping the heterogeneous use of classification models used in the Danish building industry [56] to the tool's data model. The present solution in LCAbyg is flexible, but requires the user to make a script using a guide on the tool website. In order to make this interface accessible to all users, independent of programming resources, a more convenient solution should be developed. The fact that the actual demand for automated interfaces across platforms is not fully analysed, was one of the motivations for focusing on and optimising manual user input. The need for such links will be dependent on how LCA will be integrated into consultancy, relating to the frequency of assessments, their scope and purpose in the coming years. In general, interfaces have to be developed carefully, and design workflows might have to adapt, when BIM is to be used as a reliable input method [7,57-60].

\subsection{Tool Feature-Environmental Feedback for Informing Design}

The tool calculates results and graphs for analysis immediately. When making overall inputs with consequences for the results, such as reference study period or starting year, the user is asked to confirm this choice. During building model input, the user can perform a performance comparison of library items, both default and user-generated items. The comparison feature resembles that on the modelling pages (Figure 5). This is helpful when exploring variations of items of the same component layer such as façade claddings or floorings. All results can be exported as numbers or images. 


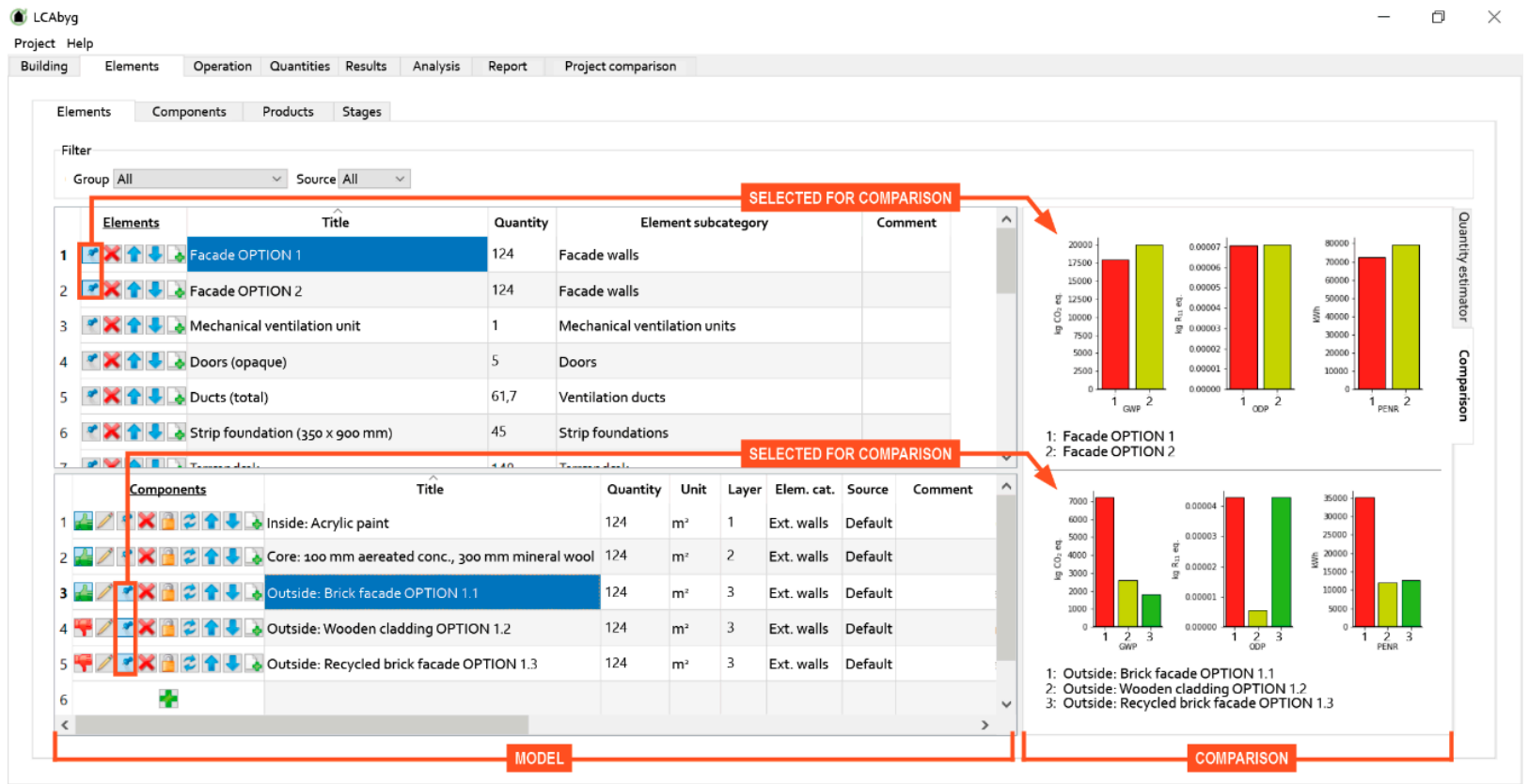

Figure 5. Quick comparison. Performance comparison of items within the same hierarchy level on the modelling pages. Here, three product and two life cycle modules are selected.

Analysis

The integrated analyses illustrate results with seven types of graphs (see examples in Figure 6). Each graph can be filtered to levels of the building model, environmental indicators, material types or reference units. Most used is the overall hotspot analysis of the 10 highest-ranking elements, components or products. The graphs include results regarding:

1. Hotspot analysis (Figure 6a);

2. Material types: Mineral, metal, insulation, wood, plastics, other;

3. Life cycle stages;

4. Accumulated embodied and operational impacts (Figure 6b);

5. Total embodied versus operational impacts;

6. Heat and electricity share in operational energy;

7. Element groups. 


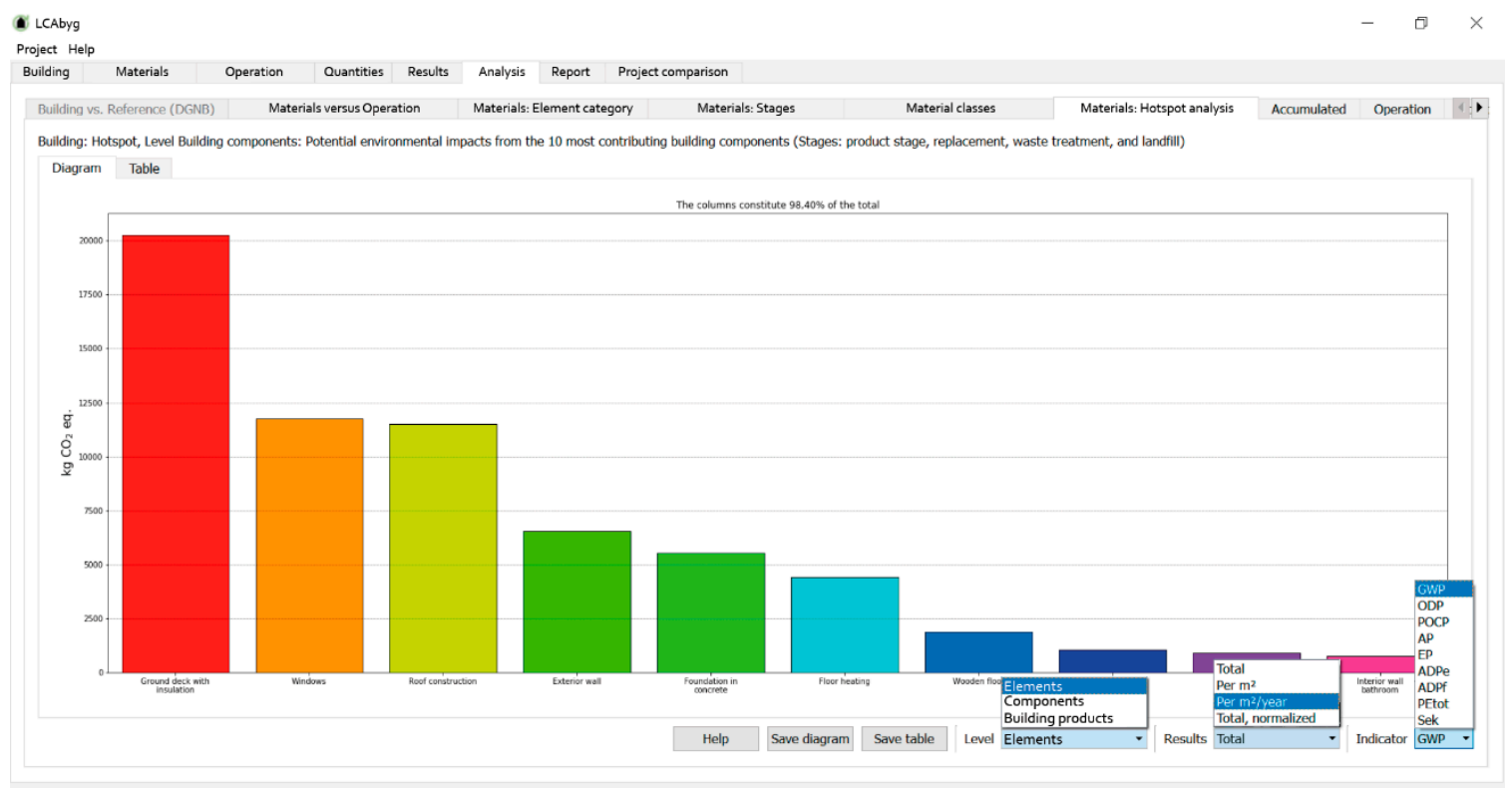

(a) Hotspot

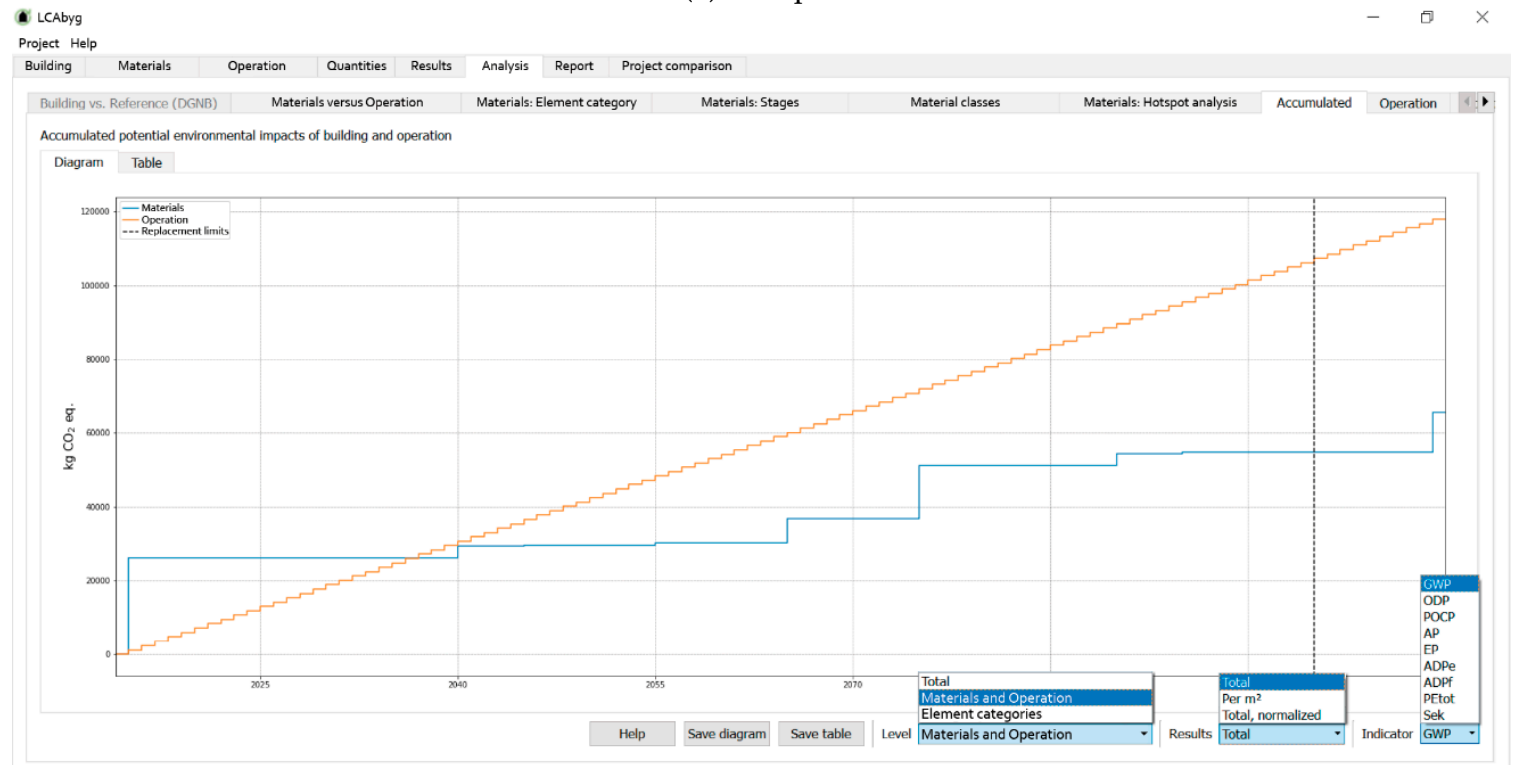

(b) Accumulated: Embodied impacts and impacts from operational energy

Figure 6. Visualisation of results in the tool. Selection of two out of seven available graph types in the tool. The Hotspot analysis shows building model items such as elements or products in order of their impact, while the Accumulated graph includes curves for operational (orange) and material (blue) impacts over the reference study period.

Additionally, a graph documenting the results regarding the DGNB reference values is included. The positive effect on lowering environmental impacts using target values have been studied [8] and expressed by responses in the user survey.

Feedback functions provide users with a palette of analysis tools for better understanding the results and the model. The offered functions allow for identifying datasets with relatively high impacts, at the levels of the product, component or element. A key purpose of analyses is suggesting improvement potential of the model, which is best done via accessible, visual means during the design process [22,60-62]. This is confirmed by the overall satisfied user rating ( $85 \%$ useful/very useful, $14 \%$ neutral, $1 \%$ less useful). 


\subsection{Tool Feature-Transparent Results}

Quantities and Results

The Quantity table sums up the project's material use (Figure 7). It includes all quantities and service lives entered by the user, and the tool's conversion into mass, aggregated on all levels of the building model. The table is useful for checking the model on manual input and unit conversion errors. Using the same structure, the results page (Figure 8) displays all impacts and replacements.

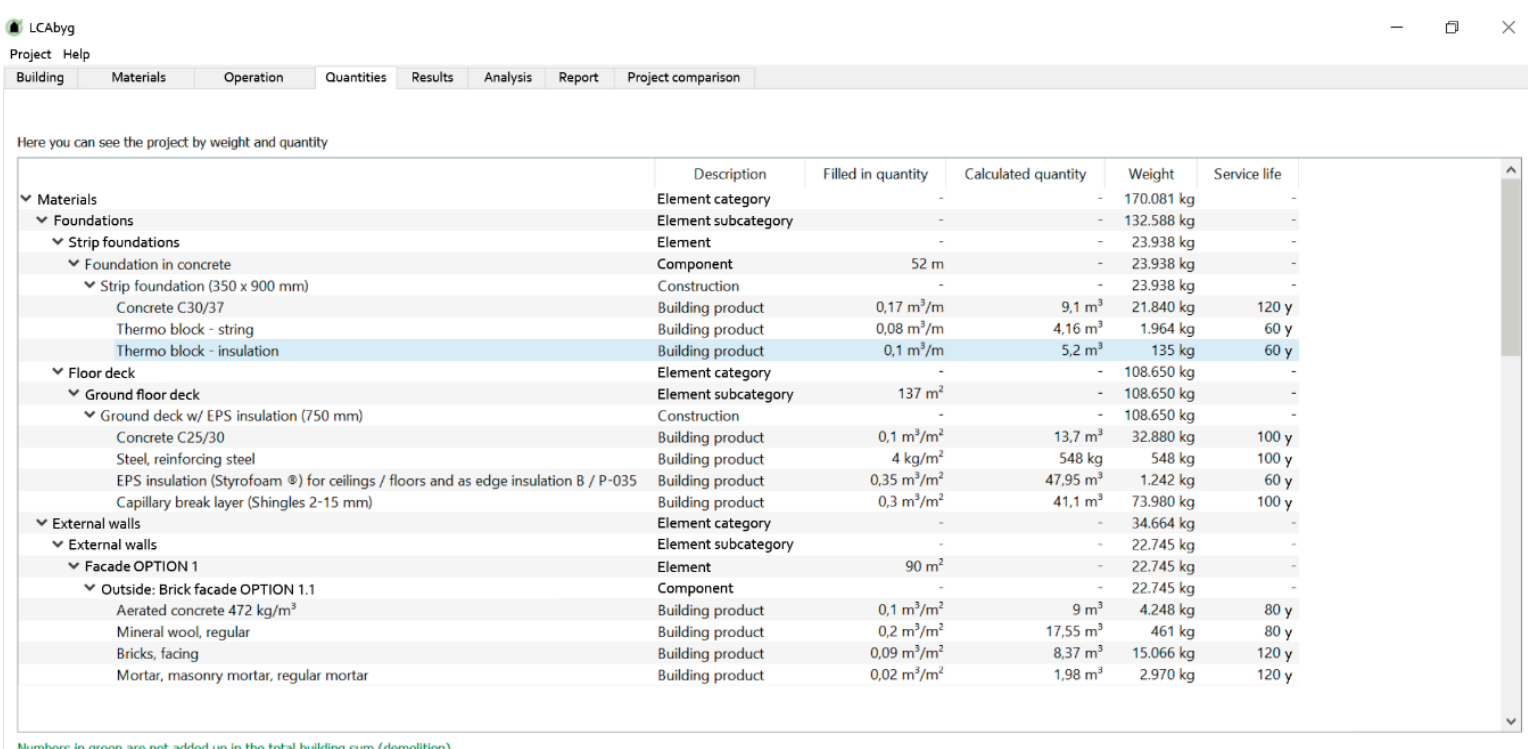

Figure 7. Quantity chart.

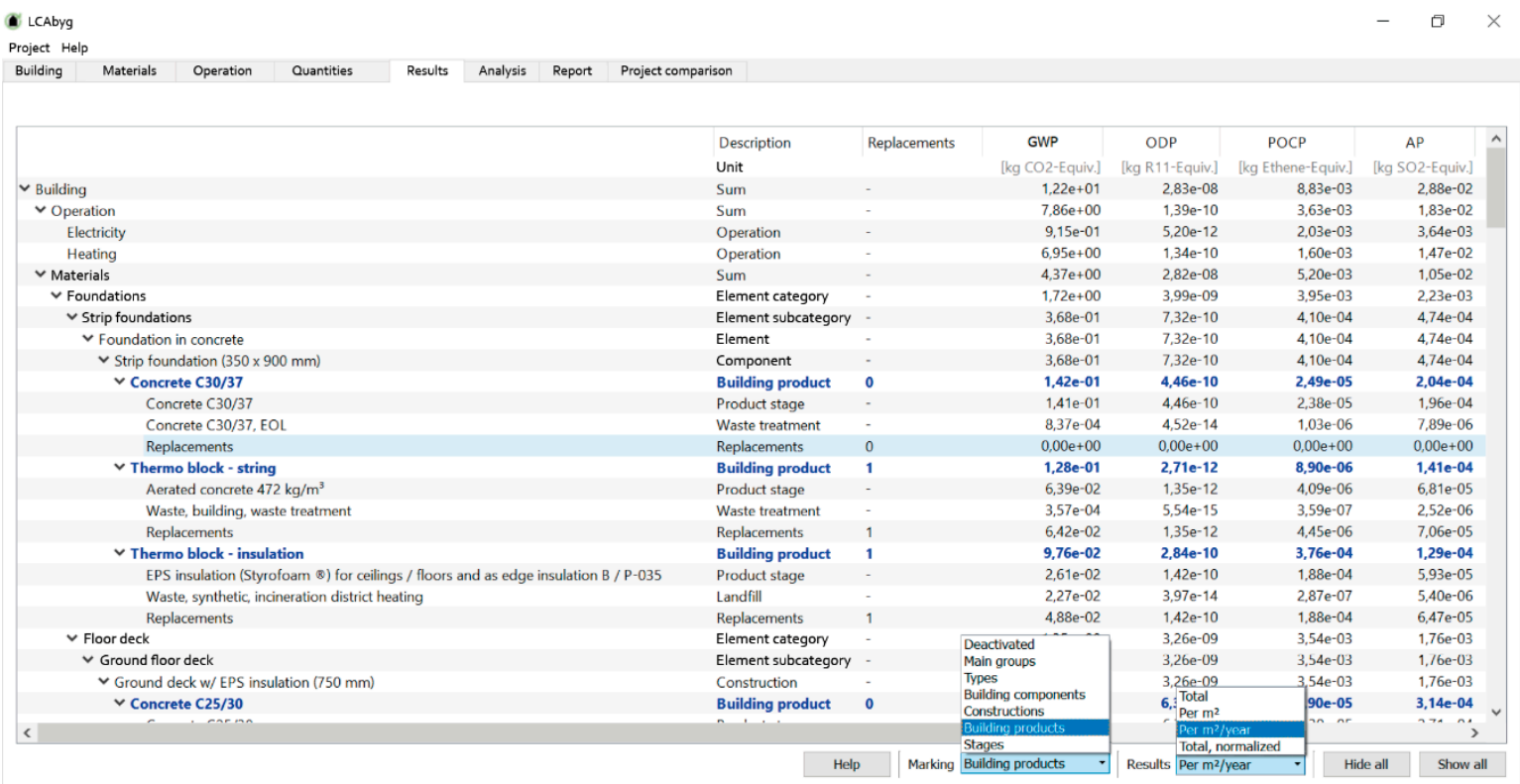

Figure 8. Results chart.

It is possible to highlight a specific hierarchy level in order to check the results or to compare specific items. As with all other output functions, available reference units can be displayed as total, per $\mathrm{m}^{2}$ and per $\mathrm{m}^{2} /$ year. All information from both views are united 
in the table file export, which gives a complete overview of input and output for further analysis, revision or visualisation outside the tool. The total results can also be reviewed by comparing the project with other projects in the tool. Analysis for uncertainty of results are not yet included in the tool. Uncertainty in an LCA can for instance be reduced by improving the data quality of sensitive input parameters, and thus improve the robustness of design decisions in the building. Future development of the tool should, therefore, consider sensitivity analysis of inputs, such as first-order approximation or Monte Carlo simulation, and scenarios. Typical uncertainties in building-LCA are temporal aspects due to the long service life of buildings. Here, scenarios to consider are the variability of reference service lives of building products, the reference study period, as well as operational energy scenarios.

The overall rating of the pages displaying quantities and results tables is positive ( $69 \%$ useful/very useful, $24 \%$ neutral, $4 \%$ less useful). However, not all respondents have made use of them due to the exercises being mostly focused on the analysis pages. Some respondents commented to have used the results and quantities tables for error inspection. The quantities and results pages were considered more difficult and not sufficiently visual. This is not viewed as a downside of the tool usability, since a variety of visualisations is provided among the analysis functions. Furthermore, visualisation can be performed freely when exporting the results. The scientific notation for LCA results is generally confusing for non-engineers such as architects or clients. In addition, some had difficulties understanding the outputs given in units of environmental indicators or resource use, most likely due to a lack of background knowledge given in the short training.

\section{Conclusions}

This paper provides insights from the development process of the Danish buildingLCA tool LCAbyg. The aim was to provide general learnings from the process and approach, which can be useful for the development of building-LCA tools tailored to other contexts.

The first research question referred to the requirements for building-LCA tools that are relevant within their respective contexts. In Denmark, the starting point of tool development was the definition of key methodological choices in order to create the foundation of a broad adoption of LCA in the industry. This process proved to be inevitably entangled with the development of the tool itself. The actual tool development work took advantage of a close stakeholder involvement before the initial launch and during the evolution of the tool. The four overall themes, available default data and settings, versatility, environmental feedback for informing design and transparent results, led the development of detailed tool features. Key elements of the tool include a default component library, based on products from the LCIA database, which are suited for modelling the most common Danish building types.

The second research question referred to the uptake of the tool by building professionals, expressed by a survey. Some responses suggest extending the library to cover a greater variety of solutions. Hence, the pre-defined component library will require regular updates or extensions. Another area in progress is the digital data flow in the building industry. With the emerging requirements for quantitative performance assessments, building design work has gradually been immersed by data analysis. Yet, at the current state, most projects do not exploit the potential of shared building models for collaboration in performance assessments-including LCA. The chosen manual input approach in LCAbyg, however, is being challenged by frontrunners in digitalisation. Better data exchange possibilities need to be added to the manual approach in order to maintain the ambition of supplying the entire range of users and providing a tool for the entire industry, not the least in a regulatory context. Participants mostly used the tool's visual data output and expressed an overall positive rating. Tool pages showing detailed lists with quantities and results were met with more reservation from users, presumably because this information aligns more 
to specialists' work. However, some interested users acknowledged the usability of these output formats for error checking or a more in-depth insight into the LCA model.

\section{Future Development}

A new tool version, supporting compliancy with the Danish voluntary sustainability class (VSC), is currently under development. Here, the new LCA modules for transport from factory to building site, the construction process and loads and benefits beyond the system boundary will be included. Clients testing VSC on their projects are asked to submit LCAbyg project files as a part of the documentation. Project data will be collected and analysed, leading to an evaluation after the two-year test period. Evaluation data will be used to review the Danish LCA method and further develop the LCA tool. Other ongoing projects will improve the usability of the tool for existing buildings, including an extension of default data, review the user interface and develop solutions for data exchange with digital building models. Furthermore, functions for uncertainty management should be included in order to support robust decision making.

Author Contributions: Conceptualization, methodology, validation K.K, R.K.Z., F.N.R. and H.B.; formal analysis, investigation, data curation, K.K; writing-original draft preparation, K.K. and R.K.Z.; writing-review and editing, K.K., R.K.Z., F.N.R. and H.B.; visualization, K.K.; project administration, K.K. and H.B.; funding acquisition, H.B. All authors have read and agreed to the published version of the manuscript.

Funding: This research was funded by the Danish Energy Authority, the Danish Transport, Building and Housing Authority and ELFORSK, grant number PSO 349-051.

Institutional Review Board Statement: Not applicable.

Informed Consent Statement: Not applicable.

Data Availability Statement: Data not applicable.

Acknowledgments: The authors wish to thank the participants of the workshops and training courses for valuable contributions to user requirements and the conducting of the survey. Thanks also go to all users of LCAbyg for their fruitful feedback. The software programming has been conducted by Christian Grau Sørensen and his team at BUILD.

Conflicts of Interest: The authors declare no conflict of interest. The funders had no role in the design of the study; in the collection, analyses, or interpretation of data; in the writing of the manuscript, or in the decision to publish the results.

\section{Appendix A}

Table A1. Questionnaire (At the Beginning of the Course).

\begin{tabular}{|c|c|}
\hline \multicolumn{2}{|c|}{ Topic: Your company } \\
\hline \multicolumn{2}{|r|}{ Q1.1 How many employees does your company have? (1 answer) } \\
\hline$\square$ & $0-2$ \\
\hline$\square$ & $3-10$ \\
\hline$\square$ & 11-20 \\
\hline$\square$ & $21-50$ \\
\hline$\square$ & $50+$ \\
\hline
\end{tabular}


Table A1. Cont.

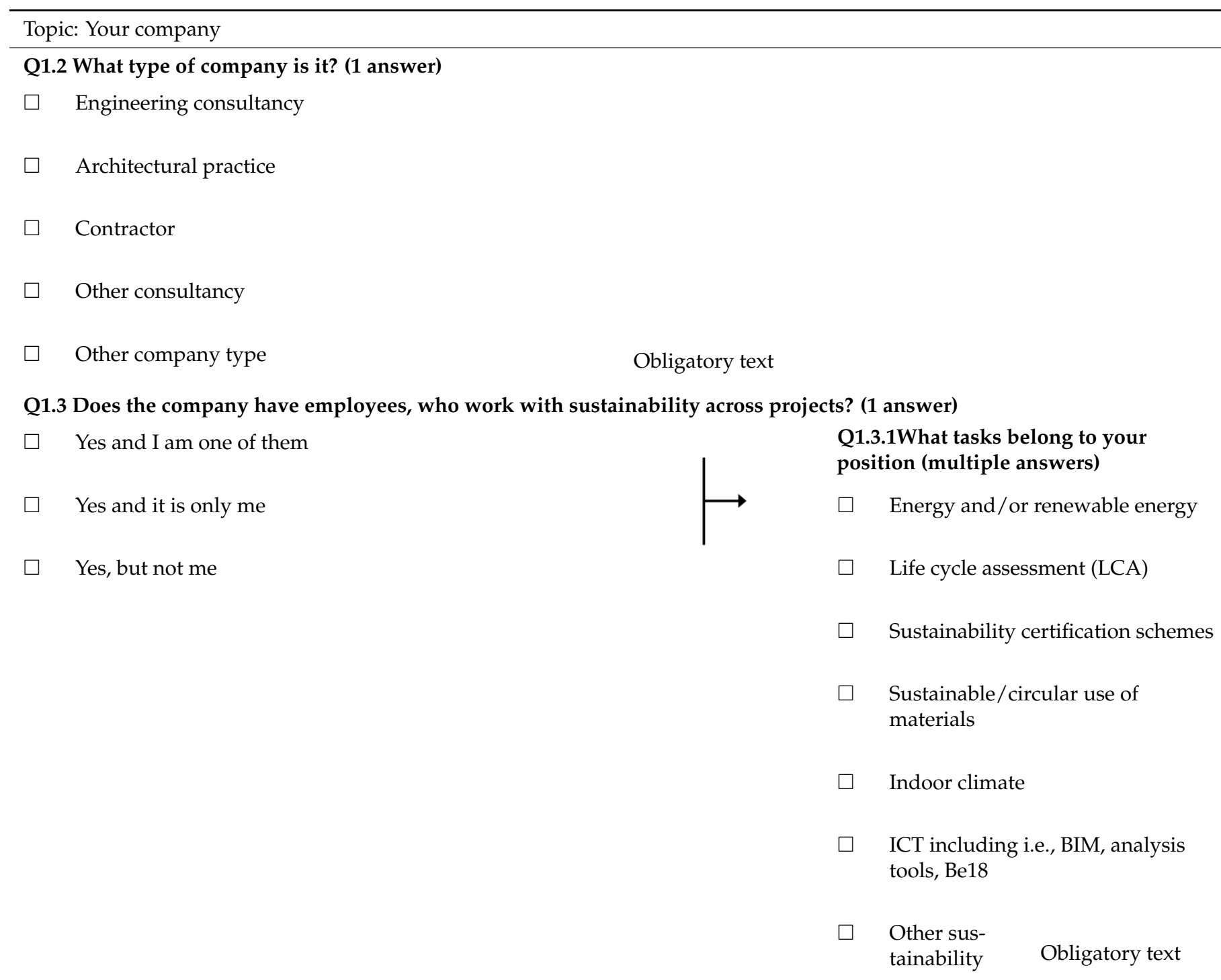

$\square \quad$ No

No, but this position is being considered for the future

I don't know

Q1.4 Is LCA part of the company's services today? (1 answer)

$\square \quad$ Yes

$\square \quad$ No

$\square \quad$ Under development

$\square \quad$ Considered

$\square \quad$ I don't know 
Table A1. Cont.
Topic: Your company
Q1.5 Has your company experienced barriers in offering LCA services? (1 answer)
$\square \quad$ Yes, the following
Obligatory text
$\square \quad$ No
$\square \quad$ I don't know
Q1.6Has you company experienced demand for LCA-based services? (1 answer)
$\square \quad$ Yes (explain)
Obligatory text
$\square \quad$ No (explain)
Obligatory text
$\square \quad$ I don't know

Topic: Your professional background

Q1.7What is your education? (multiple answers)

$\square \quad$ Architect

$\square \quad$ Engineer

$\square \quad$ Drafter

$\square \quad$ DGNB consultant

$\square \quad$ DGNB auditor

$\square \quad$ Other education in building technology or sustainable building

Obligatory text

\section{Q1.8What is your experiences as a building professional? (1 answer)}

$\square \quad$ No professional experience

$\square \quad 1-2$ years

$\square \quad 3-5$ years

$\square \quad 6-10$ years

$\square \quad 10+$ years

Q1.9What project stages have you primarily worked with during the last 5 years? (multiple answers)

$\square \quad$ Architectural competition (or similar)

$\square \quad$ Project management

$\square \quad$ Project preparation 
Table A1. Cont.

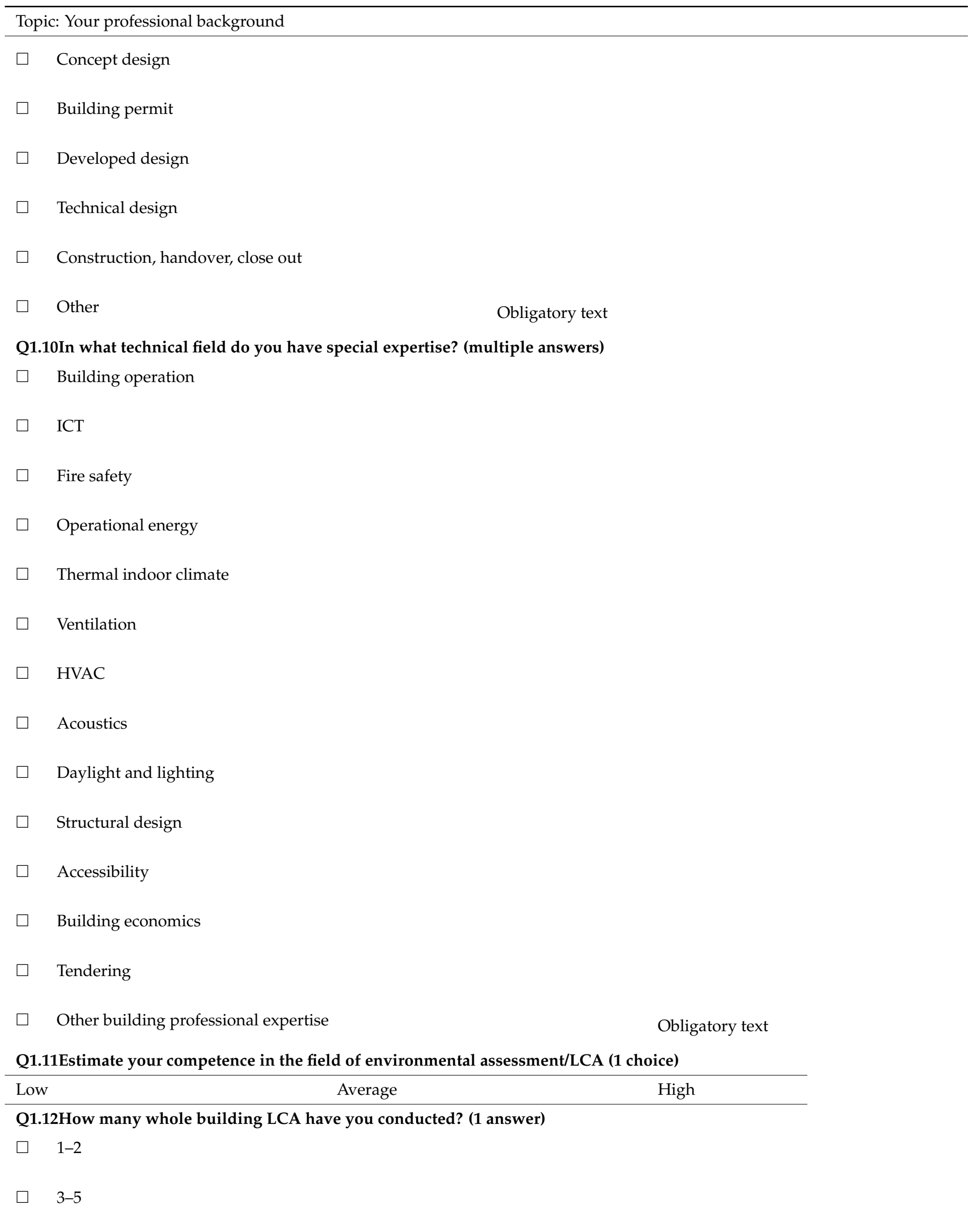


Table A1. Cont.

\begin{tabular}{|c|c|c|c|c|}
\hline \multicolumn{5}{|c|}{ Topic: Your professional background } \\
\hline \multicolumn{5}{|c|}{$\square \quad 5+$} \\
\hline$\square$ & \multicolumn{4}{|l|}{ None, but I have performed LCA on building parts } \\
\hline$\square$ & \multicolumn{4}{|l|}{ None } \\
\hline \multicolumn{5}{|c|}{ Q1.13Have you ever used LCA tools? (1 answer) } \\
\hline & Yes & \multicolumn{3}{|c|}{$\begin{array}{l}\text { Q1.13.1What LCA tools did you use? } \\
\text { (multiple answers) }\end{array}$} \\
\hline & & & $\begin{array}{l}\text { I have used L } \\
\text { education }\end{array}$ & Abyg in my \\
\hline & & $\square$ & $\begin{array}{l}\text { I have used L } \\
\text { professional }\end{array}$ & $\begin{array}{l}\text { Abyg in my } \\
\text { actice }\end{array}$ \\
\hline & & $\square$ & $\begin{array}{l}\text { I have (also) } \\
\text { used the } \\
\text { following } \\
\text { other LCA } \\
\text { tools }\end{array}$ & Obligatory text \\
\hline$\square$ & No & & & \\
\hline \multicolumn{5}{|c|}{$\begin{array}{l}\text { Q1.14What is your aim with this course? (free text) } \\
\text { Obligatory text }\end{array}$} \\
\hline
\end{tabular}

\section{Appendix B}

Table A2. Questionnaire (at the end of the course).

\begin{tabular}{ll}
\hline Topic: Your project and documentation & \\
\hline Q2.1 About your project (free text) & Obligatory text \\
$\square \quad$ Short title & Obligatory text \\
$\square \quad$ Description & \\
Q2.2 & What project documentation did you bring? \\
$\square \quad$ Hand sketches \\
$\square \quad$ Hand drawings \\
$\square \quad$ CAD model \\
$\square \quad$ CAD print \\
\hline
\end{tabular}


Table A2. Cont.

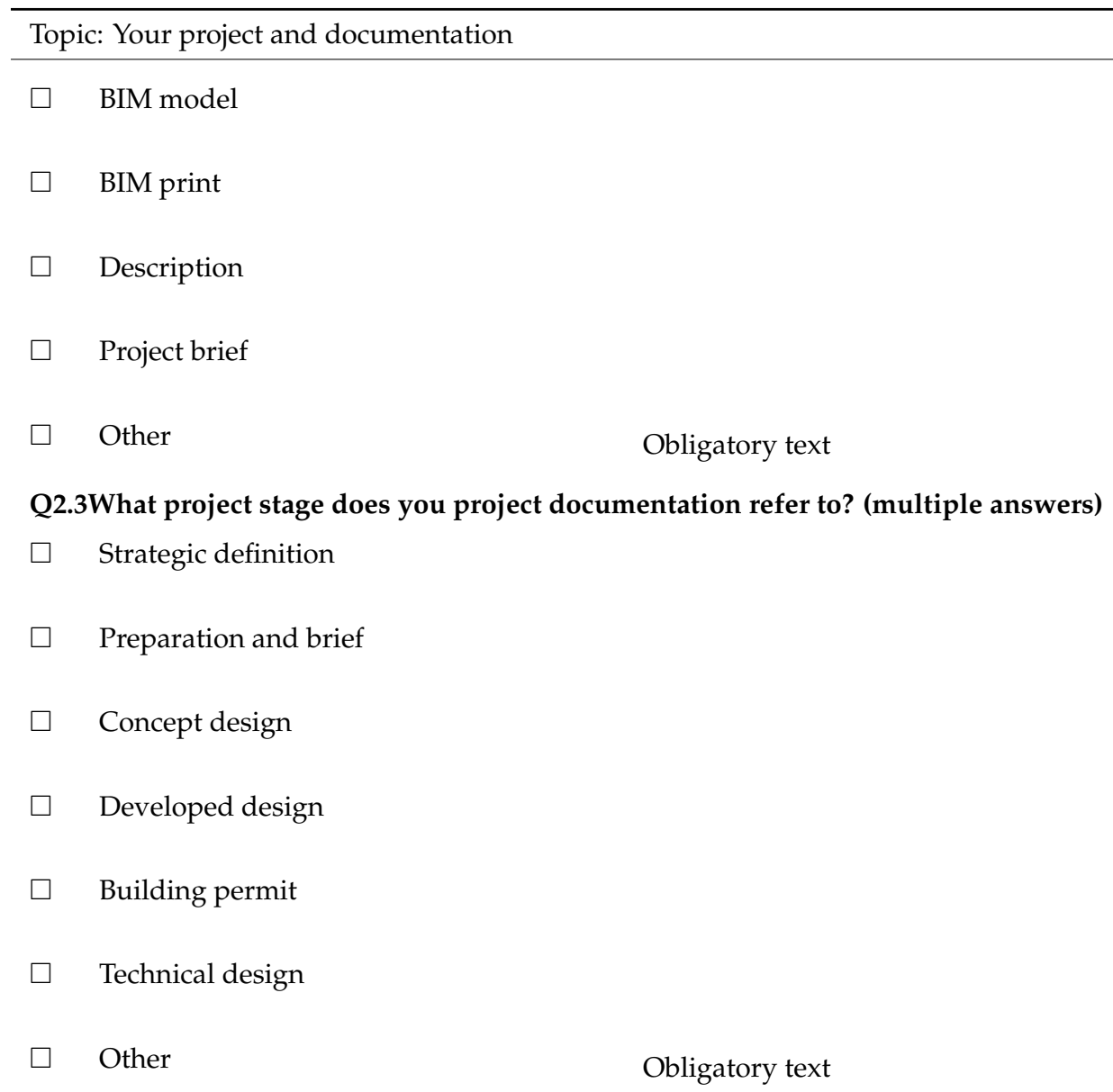

Q2.4 What is the documentation's level of definition? (1 choice)

Regarding the structural concept:

Undefined $\begin{aligned} & \text { Somehow/partly Defined } \\ & \text { defined }\end{aligned}$

Regarding the building element area:

Undefined $\quad \begin{aligned} & \text { Somehow/partly Defined } \\ & \text { defined }\end{aligned}$

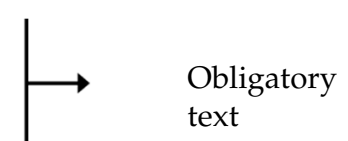

Regarding the component detailing:

\begin{tabular}{ll}
\hline Undefined & $\begin{array}{l}\text { Somehow/partly Defined } \\
\text { defined }\end{array}$ \\
\hline
\end{tabular}

Q2.5 Why did you choose this type of documentation for the project?

Q2.6 Will a BIM model be developed at a later stage?

Obligatory text

$\square \quad$ Yes

Q2.6.1 When do you expect this to happen?

Strategic definition

Preparation and brief 
Table A2. Cont.

Topic: Your project and documentation

Architectural

competition (or similar)

Concept design

Developed design

Building permit

Technical design

Other Obligatory text

$\square \quad$ No

I don't know

Other

Q2.7 Who will be responsible for the BIM model?

Obligatory text

Topic: The tool

Q2.8 How do you rate the tool's quantity estimation support?(1 choice)

Not useful Neutral Very useful

Q2.9 Do you have any comments on the quantity estimation function (figure)?

Optional text

Q2.10 How well does the tool meet the level of detail in your project documentation?(1 choice)

\begin{tabular}{lcc}
\hline Not at all & Neutral & Very well \\
\hline Optional text & & \\
Q2.11 How do you rate the available number of default components?(1 choice) \\
\hline Too few & Adequate & Too many \\
\hline
\end{tabular}

Optional text

Q2.12 How do you rate the technical quality of the default components?(1 choice)

\begin{tabular}{lll}
\hline Unacceptable & Neutral & Very high \\
\hline
\end{tabular}

Optional text

Q2.13 How do you rate the output functions?

\begin{tabular}{llllll} 
a) "Quantities" tab: & Not useful & Less useful & Neutral & Useful & Very useful \\
\cline { 2 - 5 } b) “Results" tab: & Not useful & Less useful & Neutral & Useful & Very useful \\
c) “Analysis" tab: & Not useful & Less useful & Neutral & Useful & Very useful \\
\hline
\end{tabular}


Table A2. Cont.

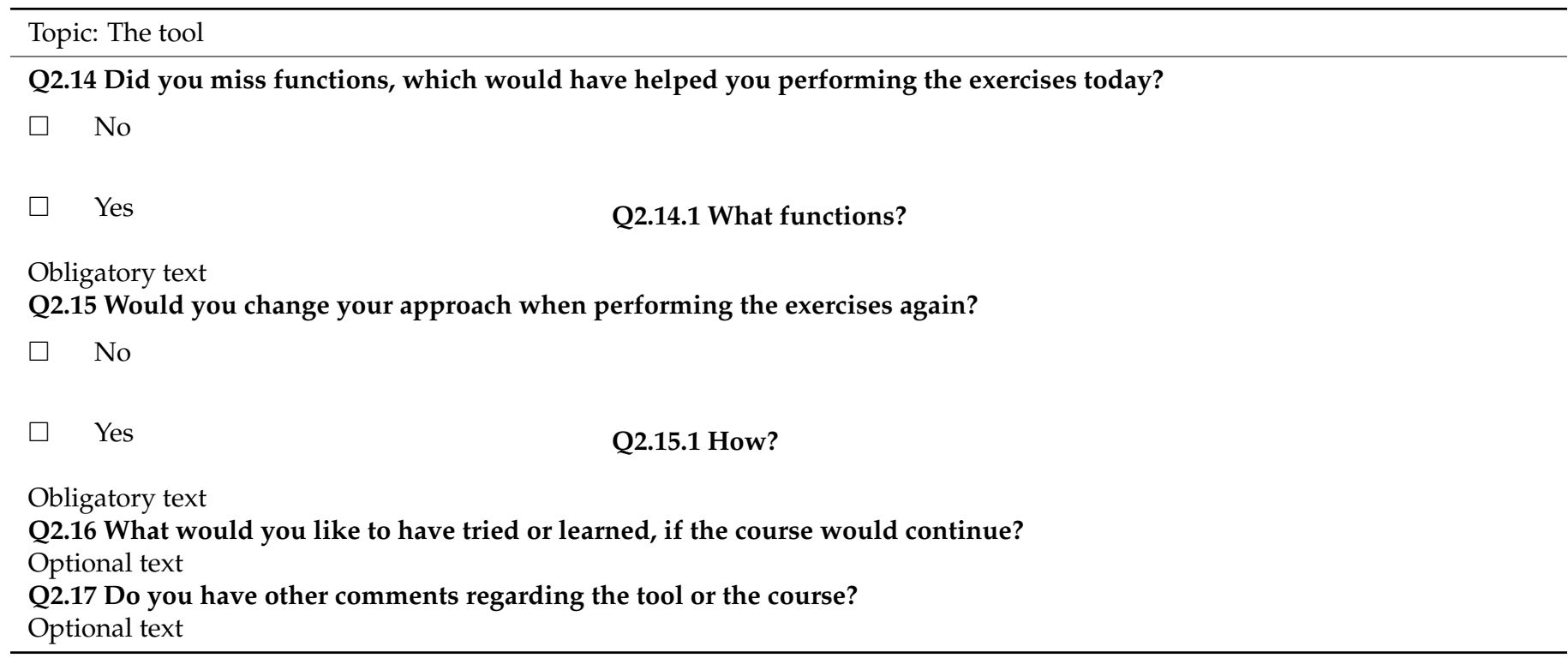

\section{References}

1. The Danish Parliament. In Aftale om Klimalov; 2019; Available online: https://www.regeringen.dk/publikationer-og-aftaletekster/ aftale-om-klimalov / (accessed on 26 November 2020).

2. International Energy Agency. 2019 Global Status Report for Buildings and Construction; IEA: Paris, France, 2019.

3. The European Parliament and the Council. Directive 2010/31/EU; The European Parliament and the Council: Brussels, Belgium, 2010.

4. The European Parliament and the Council. Directive 2012/27/EU; The European Parliament and the Council: Brussels, Belgium, 2012.

5. Blengini, G.A.; di Carlo, T. The changing role of life cycle phases, subsystems and materials in the LCA of low energy buildings. Energy Build. 2010, 42, 869-880. [CrossRef]

6. Chastas, P.; Theodosiou, T.; Kontoleon, K.J.; Bikas, D. Normalising and assessing carbon emissions in the building sector: A review on the embodied $\mathrm{CO}_{2}$ emissions of residential buildings. Build. Environ. 2018, 130, 212-226. [CrossRef]

7. Röck, M.; Passer, A.; Ramon, D.; Allacker, K. The coupling of BIM and LCA—challenges identified through case study implementation. In Proceedings of the IALCCE 2018-The Sixth International Symposium on Life-Cycle Engineering-Ghent, Ghent, Belgium, 28-31 October 2018; pp. 841-846.

8. Russell-Smith, S.V.; Lepech, M.D.; Fruchter, R.; Littman, A. Impact of progressive sustainable target value assessment on building design decisions. Build. Environ. 2015, 85, 52-60. [CrossRef]

9. Passer, A.; Ouellet-Plamondon, C.; John, V.; Kenneally, P.; Habert, G. The impact of future scenarios on building refurbishment strategies towards plus energy buildings. Energy Build 2016, 124, 153-163. [CrossRef]

10. Frischknech, R.; Balouktsi, M.; Lützkendorf, T.; Aumann, A.; Birgisdottir, H.; Ruse, E.G.; Hollberg, A.; Kuittinen, M.; Lavagna, M.; Lupišek, A.; et al. Environmental benchmarks for buildings: Needs, challenges and solutions-71st LCA forum. Int. J. Life Cycle Assess 2019, 24, 2272-2280.

11. Lützkendorf, T. Assessing the environmental performance of buildings: Trends, lessons and tensions. Build. Res. Inf. 2018, 46, 594-614.

12. Stichting Bouwkvaliteit. Determination Method-Environmental Performance Buildings and Civil Engineering Works 3.0; 2019; Available online: https: / / milieudatabase.nl/downloads/05-determination-method-v3-0-jan2019-en/ (accessed on 26 November 2020).

13. Finish Ministry of the Environment. Method for the Whole Life Carbon Assessment of Buildings_2019:13; 2019; Available online: https: / / www.google.com/url?sa=t\&rct=j\&q=\&esrc=s\&source=web\&cd=\&ved=2ahUKEwiRjPi6lsPuAhVJAhAIHZiKA3 4QFjAAegQIARAC\&url=https\%3A\%2F\%2Fjulkaisut.valtioneuvosto.fi\%2Fbitstream\%2Fhandle\%2F10024\%2F161796\%2FYM_ 2019_23_Method_for_the_whole_life_carbon_assessment_of_buildings.pdf\%3Fsequence $\% 3$ D $1 \% 26$ isAllowed $\% 3$ Dy\&usg= AOvVaw2tL_b_CEMJLzTLnpvHJ276 (accessed on 26 November 2020).

14. Finansdepartementet. Klimadeklaration för Byggnader. Ds 2020:4; 2020; Available online: https://www.regeringen.se/4a4044/ contentassets/3e13a513131b447f8b1e41eddcbbf6b5/klimatdeklaration-for-byggnader-ds-20204.pdf (accessed on 26 November 2020).

15. Norsk Standard. Method for Greenhouse Gas Calculations for Buildings- NS 37:2018; Standard Norge: Oslo, Norway, 2018.

16. Vejledning om den Frivillige Bæredygtighedsklasse; The Danish Transport Construction and Housing Authority: København, Danish, 2020; p. 91. 
17. Weißenberger, M.; Jensch, W.; Lang, W. The convergence of life cycle assessment and nearly zero-energy buildings: The case of Germany. Energy Build. 2014, 76, 551-557. [CrossRef]

18. Marsh, R.; Rasmussen, F.N.; Birgisdottir, H. Embodied Carbon Tools for Architects and Clients Early in the Design Process; Pomponi, C.D.W.F., Moncaster, A., Eds.; Springer: Berlin/Heidelberg, Germany, 2018.

19. Basbagill, J.; Flager, F.; Lepech, M.; Fischer, M. Application of life-cycle assessment to early stage building design for reduced embodied environmental impacts. Build. Environ. 2013, 60, 81-92. [CrossRef]

20. John, V. Derivation of Reliable Simplification Strategies for the Comparative LCA of Individual and Newly Built Swiss Apartment Buildings. Ph.D. Thesis, Swiss Federal Institute of Technology in Zurich, Zürich, Switzerland, 2013.

21. Lamé, G.; Leroy, Y.; Yannou, B. Ecodesign tools in the construction sector: Analyzing usage inadequacies with designers' needs. J. Clean. Prod. 2017, 148, 60-72. [CrossRef]

22. Meex, E.; Hollberg, A.; Knapen, E.; Hildebrand, L.; Verbeeck, G. Requirements for applying LCA-based environmental impact assessment tools in the early stages of building design. Build. Environ. 2018, 133, 228-236. [CrossRef]

23. Olinzock, M.A.; Landis, A.E.; Saunders, C.L.; Collinge, W.O.; Jones, A.K.; Schaefer, L.A.; Bilec, M.M. Life cycle assessment use in the North American building community: Summary of findings from a 2011/2012 survey. Int. J. Life Cycle Assess. 2015, 20, 318-331. [CrossRef]

24. Saunders, C.L.; Landis, A.E.; Mecca, L.P.; Jones, A.K.; Schaefer, L.A.; Bilec, M.M. Analyzing the Practice of Life Cycle Assessment. J. Ind. Ecol. 2013, 17, 777-788. [CrossRef]

25. European Committee for Standardization CEN/TC350. EN 15978:2012; CEN: Brussels, Belgium, 2012.

26. Schlanbusch, R.D.; Fufa, S.M.; Häkkinen, T.; Vares, S.; Birgisdottir, H.; Ylmén, P. Experiences with LCA in the Nordic Building Industry-Challenges, Needs and Solutions. Energy Procedia 2016, 96, 82-93. [CrossRef]

27. De Wolf, C.; Pomponi, F.; Moncaster, A. Measuring embodied carbon dioxide equivalent of buildings: A review and critique of current industry practice. Energy Build. 2017, 140, 68-80. [CrossRef]

28. Stichting Bouwkvaliteit. Bepalingsmethode Milieuprestatie Gebouwen en GWW-werken Versie 3.0; Stichting Bouwkvaliteit: Rijswijk, The Netherlands, 2019; p. 82.

29. Danish Transport, Construction and Housing Authority. Den Frivillige Bæredygtighedsklasse. 2020. Available online: https: / / baeredygtighedsklasse.dk/ (accessed on 2 June 2020).

30. Kuittinen, M.; Häkkinen, T. Reduced carbon footprints of buildings: New Finnish standards and assessments. Build. Cities 2020, 1, 182-197. [CrossRef]

31. Athena Impact Estimator for Buildings. Available online: https://calculatelca.com/software/impact-estimator/ (accessed on 26 November 2020).

32. Baubook Eco2soft. Available online: https://www.baubook.info/eco2soft/ (accessed on 26 November 2020).

33. CAALA GmbH. Available online: https:/ / caala.de/ (accessed on 26 November 2020).

34. Federal Institute for Research on Building, Urban Affairs and Spatial Development. Available online: https://www.bauteileditor. de (accessed on 26 November 2020).

35. Bionova Ltd. Available online: https: / / www.oneclicklca.com/ (accessed on 26 November 2020).

36. Anavitor. Available online: http:/ / www.anavitor.se/Anavitor (accessed on 26 November 2020).

37. BM-Byggsektorns Miljöberäkningsverktyg. Available online: https://www.ivl.se/projektwebbar/byggsektorns-miljoberakningsverktyg. html (accessed on 26 November 2020).

38. Danish Government. Vejen til et Styrket Byggeri i Danmark—Regeringens Byggepolitiske Strategi; Danish Government: Copenhagen, Danish, 2014.

39. Birgisdottir, H.; Sørensen, C.G.; Rasmussen, F.N.; Skovgaard, M.; Aggerholm, S. LCAbyg Version1; Aalborg University: Copenhagen, Denmark, 2015.

40. Birgisdottir, H.; Rasmussen, F.N. Development of LCAbyg: A National Life Cycle Assessment Tool for Buildings in Denmark. In Proceedings of the IOP Conference Series: Earth and Environmental Science, Saint Petersburg, Russian, 17-18 April 2019; Volume 290.

41. Rasmussen, F.N.; Birgisdottir, H. Development of the LCAbyg tool: Influence of user requirements and context. In Proceedings of the Sustainable Built Environment Conference 2016 in Hamburg: Strategies, Stakeholders, Success factors, Hamburg, Germany, 7-11 March 2016; pp. 380-389.

42. Kanafani, K.; Birgisdottir, H.; Zimmermann, R.K.; Sørensen, C.G. LCAbyg 4; Aalborg University: Copenhagen, Denmark, 2019.

43. Birgisdóttir, H.; Hansen, K.; Haugbølle, K.; Hesdorf, P.; Olsen, I.S.; Mortensen, S. Bæredygtigt Byggeri: Afprøvning af Certificeringsordninger til Måling af Bæredygtighed i Byggeri; Byggeriets Evaluerings Center: København K, Denmark, 2010.

44. Gantner, J.; Lenz, K.; Horn, R.; von Both, P.; Ebertshäuser, S. Ökobau.dat 3.0-Quo Vadis? Buildings 2018, 8, 129. [CrossRef]

45. European Committee for Standardization CEN/TC350. EN 15804:2012+A1:2013; CEN: Brussels, Belgium, 2013.

46. CML-IA Characterisation Factors; University of Leiden: Leiden, The Netherlands, 2016.

47. Aagaard, N.-J.; Brandt, E.; Aggerholm, S.; Haugbølle, K. Lifespan of building components when assessing sustainability and total economy. Build Ele Assess Sus Life Cycle Cost. 2013, 30, 48.

48. COWI A/S. New Emission Factors for Electricity and District Heating; COWI A/S: Kongens Lyngby, Denmark, 2016. 
49. Energiforskning.dk. Low energy buildings and embodied energy in a sustainability perspective: New knowledge and tools for consultants and clients. 2019. Available online: https:/ / energiforskning.dk/en/projects/detail?program=All\&teknologi=All\&field_ bevillingsaar_value $=\&$ start=\&slut=\&field_status_value=All\&keyword=lowenergybuildingsandembodiedenergy \&page $=0$ (ac cessed on 22 January 2020).

50. Kanafani, K.; Zimmermann, R.K.; Rasmussen, F.N.; Birgisdóttir, H. Early Design Stage Building LCA using The LCAbyg Tool: New Strategies For Bridging The Data Gap. IOP Conf. Ser. Earth Environ. Sci. 2019, 323, 12117. [CrossRef]

51. Zimmermann, R.K.; Kanafani, K.; Rasmussen, F.N.; Birgisdóttir, H. Early Design Stage Building LCA using the LCAbyg tool: Comparing Cases for Early Stage and Detailed LCA Approaches. IOP Conf. Ser. Earth Environ. Sci. 2019, 323, 12118. [CrossRef]

52. Kanafani, K.; Zimmermann, R.K.; Birgisdóttir, H.; Rasmussen, F.N. LCA in Early Building Design: Introduction to the Method and Environmental Profile Examples (in Danish); Aalborg University: Copenhagen, Denmark, 2019.

53. Rambøll Management Consulting. SurveyXact. Available online: https://www.surveyxact.dk/ (accessed on 22 January 2020).

54. Baubook GmbH. Baubook; Available online: https:/ / www.firmenabc.at/baubook-gmbh_Dzge (accessed on 26 November 2020).

55. Attia, S.; Hensen, J.L.M.; Beltrán, L.; de Herde, A. Selection criteria for building performance simulation tools: Contrasting architects' and engineers' needs. J. Build. Perform. Simul. 2012, 5, 155-169. [CrossRef]

56. Sørensen, N.L.; Gottlieb, S.C. SBi 2018:08_Byggebranchens Anvendelse af IKT; Aalborg University: Copenhagen, Denmark, 2018.

57. Cavalliere, C.; Habert, G.; Dell'Osso, G.R.; Hollberg, A. Continuous BIM-based assessment of embodied environmental impacts throughout the design process. J. Clean. Prod. 2019, 211, 941-952. [CrossRef]

58. Hollberg, A.; Genova, G.; Habert, G. Evaluation of BIM-based LCA results for building design. Autom. Constr. 2020, $109,102972$. [CrossRef]

59. Soust-Verdaguer, B.; Llatas, C.; García-Martínez, A. Critical review of bim-based LCA method to buildings. Energy Build. 2017, 136, 110-120. [CrossRef]

60. Tsikos, M.; Negendahl, K. Sustainable Design with Respect to LCA Using Parametric Design and BIM Tools. In Proceedings of the World Sustainable Built Environment Conference 2017, Hong Kong, China, 5-7 June 2017.

61. Resch, E.; Lausselet, C.; Brattebø, H.; Andresen, I. An analytical method for evaluating and visualizing embodied carbon emissions of buildings. Build. Environ. 2020, 168, 106476. [CrossRef]

62. Miyamoto, A.; Allacker, K.; de Troyer, F. Visual tool to integrate LCA and LCC in the early design stage of housing. IOP Conf. Ser. Earth Environ. Sci. 2019, 323, 12161. [CrossRef] 